\title{
Real Estate Risk Analysis: The Case of Caserma Garibaldi in Milan
}

\author{
Leopoldo Sdino ${ }^{1, *}$, Paolo Rosasco ${ }^{2}$ and Sara Magoni ${ }^{1}$ \\ 1 Department of Building Environment Science and Technology, Polytechnic of Milan, 20133 Milan, Italy; \\ saramarta.magoni@polimi.it \\ 2 Department of Architecture and Design, University of Genoa, 16137 Genoa, Italy; rosasco@arch.unige.it \\ * Correspondence: sdino@polimi.it; Tel.: +39-022-399-5732
}

Received: 26 October 2017; Accepted: 28 December 2017; Published: 3 January 2018

\begin{abstract}
The global economic crisis and deep financialization processes recently suffered by the real estate market have exposed the latter to further and greater risks. Against this, the importance of real estate risk management has noticeably grown within the dynamics of both markets, real estate and finance. Therefore, the aim of this paper is to develop a comprehensive tool for the risk rating that will consider both the systematic and idiosyncratic risks possibly incurred during a real estate operation, in order to deliver their actual magnitude. It will be composed of 33 criteria whose weights are determined through the application of an analytic hierarchic process on a panel of market operators. This tool is primarily addressed to investors since it allows making strategic decisions while being supported by an analytical procedure that also ensures transparency of the conduct for the rating. An application of the presented tool within the decision-making procedure of the re-functionalization of a former barracks in Milan's city center is then described; this case study will also constitute an opportunity to highlight the strong relationship that occurs between the profitability of an operation and the risk incurred.
\end{abstract}

Keywords: real estate; risk management; rating tool

\section{Introduction}

In recent years, real estate has undergone a deep transformation caused by several ever-increasing financialization processes (Degennaro 2008). Becoming vulnerable to the typical risks of a financial investment, the real estate market has progressively lost its peculiar stability that, being previously almost immune from any recession phenomena, had caused investors to consider it a "refuge sector" (Maggi 2014).

The main reason of such evolution of the market is to be found in the crisis of recent years that has aligned it to global economic developments and fluctuations. The interconnection of global economies, the interdependence between real estate and mortgage credit, and the rapid transformation of the international context have, thus, determined the need of a significant development within the sector of real estate valuations (Tecnoborsa 2011). In this context, the interpenetration of the real estate market with finance is, thus, unavoidable and, despite the banking system's attempts to fight it with several countermeasures, it has determined the need to research and develop ever more reliable and transparent rating systems and evaluation procedures. Nevertheless, there still has not been an adequate response in terms of the development and distribution of tools and protocols specifically dedicated to real estate risk rating. This fact, along with the great amount of interest that emerged from both financial and real estate operators, makes this topic particularly relevant.

Therefore, this work develops a proposal for a risk-rating tool that is specifically dedicated to real properties that considers and assesses, individually, the whole collection of risks involved in a real estate operation. 
The aim of this work is to define a useful tool for public administrations or private investors for the evaluation of risk in a real estate initiative within the initial design phases (urban planning, etc.) with particular reference to the definition of quantities and uses (square meters of residences, offices, parking areas, public services, etc.).

The case study enabled to establish - for two different design assumptions for the recovery of the former Caserta Garibaldi located in the Municipality of Milan-the respective levels of risk for economic sustainability of the investment; the results show that the most lucrative hypothesis for the private operator is also the one with the highest level of risk for the successful outcome of the investment.

For public administrations, the knowledge of risk factors allows to define sustainable pathways for recovery and re-localization of areas and buildings and more efficient administrative procedures, especially in the presence of different operators, each bearers of legitimate interests. Careful planning of interventions is crucial not only for private promoters awaiting adequate economic returns, but also for public administrations that get these public spaces and services for the community.

\section{Real Estate Risk}

The concept of risk refers to the possibility that an action or a choice might lead to an undesirable event. It is a probabilistic concept since it is definable as the combination of severity of the feared damage and its probability.

When dealing with risk, it is crucial to distinguish it from the concept of uncertainty. In a risky situation, an action is carried out owning a complete and exhaustive knowledge of its possible consequences while, with uncertainty, no objective tool useful for making strategic choices is available. In short, the economist Frank Knight proposed a clear distinction on this topic; uncertain situations are the ones where the unknown is, in fact, unknown (unknown-unknown), while risky situations are the ones where the unknown is known and assessable (known-unknown) (Knight 1921).

Every human action and every transformation, departing by definition from a condition of immobility, intrinsically implies some risks. What is to be avoided is not the risk for itself, which would also be counterproductive for the development, but the excessive one. Therefore, it is only in that case that the risk manager will intervene by correctly evaluating the risk and, consequently, by significantly reducing it until a threshold of acceptability.

As mentioned above, risk can be defined as the direct relationship that occurs between a negative event's probability and its severity. Risk assessment is, thus, operatively, the quantification of these two factors and their combination. In this way, it is possible to acquire adequate informative tools for intervening consciously with the, eventual, most appropriate safety measures.

However, it is necessary to clarify that these tools, no matter how sophisticated they are, cannot predict nor prevent the advent of the so-called "black swan" (Nassim 2007), which is a tragic event of large magnitude and serious consequences that is extremely rare and, therefore, that always comes unexpectedly. In fact, risk-rating tools are effective only for those risks whose "probability" factor is relevant. This condition should always be kept in mind when assessing the risk of an operation, but it does not make these tools any less useful.

As mentioned, real properties, just like any other financial asset, constitute investment goods; thus, their acquisition or development involves initial monetary outflows that will only subsequently generate positive cash flows. Nevertheless, future cash flows are uncertain for both their timing and their amount. It is to this variability of possible results that the concept of risk is related. However, the real estate market is not unitary, its knowledge is imperfect, it is cyclical (Janssen et al. 1994; Festa et al. 2012; Reddy's Group 2016) and segmented. It is, thus, an atypical market, imperfect, which widely departs from the conditions of perfect competition assumed by economists. As such, the development of techniques for risk assessment of a real estate operation has to face particular difficulties.

The development of a property is a long and complex operation that involves numerous subjects; for this reason, it is perpetually threatened by a great variety of risks. 
Therefore, in order to verify the sustainability of an operation, it is advisable to carefully consider the nature and the extent of each possible risk. As a consequence of the financialization of the market, this variety of risks can be broken down using the same concept applied for financial ones, that is to say, the distinction between systematic and unsystematic (or idiosyncratic) risks. The first ones are those shared with all the activities exchanged within the sector; therefore, they are hardly diversifiable. They are the so-called "market risks".

The second ones are those associated to the characteristics of the specific market activity and they refer to the peculiarity of the single asset. This categorization has been used in many studies; each one of them has focused primarily on the assessment and management of systematic risks (Baroni et al. 2008), of idiosyncratic risk (Bourassa et al. 2009; Shao et al. 2015; Peng and Thibodeau 2017), or, as this work also aims, of both (Capozza and Schwann 1990).

In order to correctly run an operation, it is appropriate to manage the whole variety of risks; focusing only on some of them can be counterproductive since others might be overlooked and, thus, being uncontrolled, might lead to the failure of the whole operation.

Therefore, to gain the actual perception of risks incurred during a real estate operation, it is necessary to use tools that allow their coordinate assessment and management. This is the path that the estimative sector is taking, with the development and the application of real estate valuation tools, such as the International Valuation Standards (International Valuation Standards Council 2013) and the European Valuation Standards (TEGoVA 2012) and, more recently, of real estate risk rating tools (Manganelli et al. 2014; D'alpaos and Canesi 2014; Ribeiro et al. 2017; Zheng et al. 2015; Benedetto 2015; Jiang et al. 2007). Among these it is worth mentioning, since it is more widespread and better structured, at the European level, the Property and Market Rating developed by TEGoVA in 2003 (TEGoVA 2003), and, at the national level, the Real Estate Risk (RER) proposed by Cacciamani (Cacciamani 2003).

In fact, the interest that market operators have shown in risk-rating procedures is relatively new. In the past, until the advent of the crisis, these were considered almost superfluous since there has been, almost exclusively, a consistent increase in the sector's market values. However, since the market has faced an extraordinary deep recession and, thus, a revolution in its settings, it is now commonly accepted that risk-rating procedures constitute a useful tool for everyone who operates within the real estate market.

\section{Methodology}

In order to identify which are the criteria involved in a real estate operation's success, a panel of six different real estate categories (or groups) of operators have been consulted (Figure 1).

The purpose of using this method of criteria collection was to not leave out from the final tool any important risk; in fact, the limit recognized in some of the existing risk rating tools was their focus on only one side of the risk, mostly financial or architectural, often as a consequence of their developer's professional profile, thus leaving other risks dangerously uncontrolled.

In a first step, each group of operators have selected the most important criteria (or characteristics) which must be evaluated during the design and planning phase. The selection has been developed through the brainstorm technique ${ }^{1}$; because of the different professional and technique experiences of each group's components, a harmonization of the criteria's terms have been developed. After this, 33 criteria have been defined; they are distributed in four macro-criteria (or macro-categories) in accordance with their reference framework: Location Risk (broken down in National Environment Risk and Extrinsic Characteristics Risk), Local Market Risk, Property's Intrinsic Characteristics Risk and Income Risk (Table 1). Once the collection of criteria was completed, their weighting has

1 Each group components must answer at this questions: "Which are the characteristics whose presence/absence or quality level can represent a risk to a good result of a real estate initiative?" The concept of "good result" is declined in different way by each group (e.g.: private operators like "builders" or "real estate promoters" have considered a "good result" the economic sustainability of the initiative while the "public authorities" the social sustainability. 
been performed through the application of the pairwise comparison approach utilized within the analytic hierarchy process (AHP) a multicriteria evaluation method proposed by Saaty in the 1980s (Saaty 1980, 1988, 1990). The AHP assists with decision-making processes by providing decision-makers with a structure to organize and evaluate the importance of various objectives and the preferences of alternative solutions to a decision.

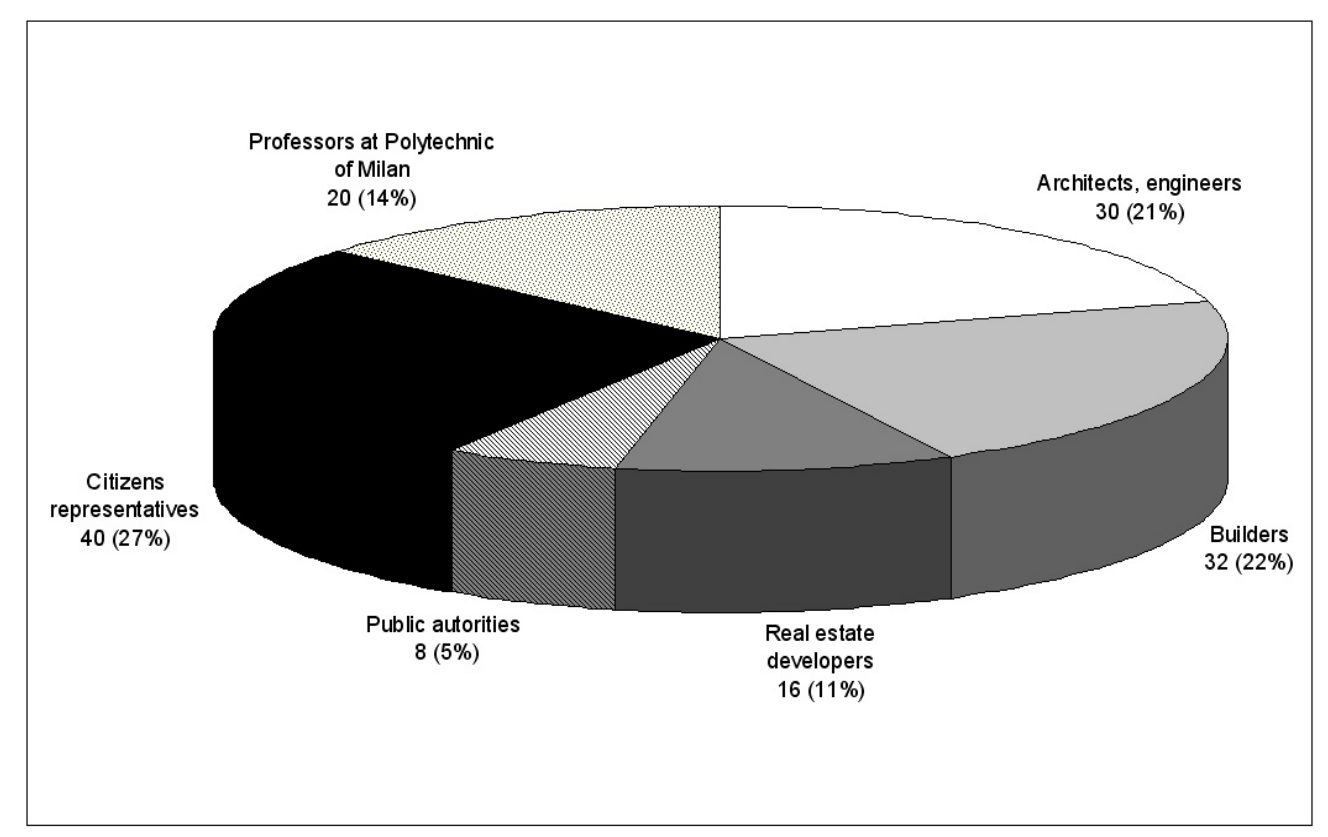

Figure 1. Panel's composition.

The technique is applied in different complex decisional contexts: industry, health, logistics, military, government, manufacturing, agriculture, education, telecommunication, etc. (de FSM Russo and Camanho 2015; Ho and Ma 2017; Ho 2008); in real estate, it has been used in several case studies: to assign the weight of six quality factors and 30 quality sub-factors in a building center district (Ho et al. 2005); to select an efficient retrofit scenarios for buildings (Kušar et al. 2013; Cecconi et al. 2017); to analyze a family house purchase decision (Wang 2013; Lin and Lin 2013); to select and weight the criteria meaningful to evaluate the quality of public space from a social point of view (Palicki 2015); and to rank the real estate investment environment (Kozioł-Kaczorek 2014) of four residential properties located in Warsaw by means of six weighted criteria (Kozioł-Kaczorek 2014). One of the major strengths of the AHP is the use of pairwise comparison to derive, with respect to an objective, the importance (weight) of each criteria (the significant elements of the decision-making problem) and the ratio scale priorities (alternatives). It is a process of comparing the relative importance (or preference) of two elements with respect to another element in the level above. This procedure starts with the compilation of a square, symmetric, and diagonal matrix where the relative relevance of two criteria (or sub-criteria) at a time are determined according with each compiler's professional experience and opinions. The relative importance of an element respect to another is expressed through the Saaty scale; it is structured with nine scores: 1 means they have the equal relevance; scores from 2 to 9 express increasing levels of importance of one element to other (9 expresses the highest prevalence of one to another). Then, these data are used to derive the weight of each criteria. For doing this, the vector that expresses the relative priorities of elements (criteria or sub-criteria) is defined by extracting the main eigenvector of the pairwise comparison matrix; after this, each component of the eigenvectors is standardized and the numerical value obtained (expressed in percent), represents the relative importance of the correspondent elements.

In this case study the pairwise comparison has been developed in two subsequent steps: 
1. First, to weight the four groups of macro-criteria (Location, Local market, Intrinsic and Income characteristics). The pairwise comparison is developed between the four groups (two at a time) and the prevalence expresses the influence of the group with respect to the result of the real estate initiative (Figure 2). The groups of criteria which result from the higher importance for the result of a real estate initiative, in terms of are those related to the conditions of the local real estate market ("Local market characteristics") and the perceived profitability of the real estate asset (Income characteristics-Table 1), have $30 \%$ of the weight ${ }^{2}$;

2. Second, to weight each of the 33 selected criteria (or characteristics) within each group. In the first group (Location characteristics), the criteria with the higher importance is "Overall economic development and international attractiveness" (GDP growth, inflation, infrastructures, etc.) has $40 \%$ of the weight, followed by "Political, law, taxation and currency conditions" with $25 \%$; in the second group, the criteria "Use" has $30 \%$ of the weight, followed by the "Numbers of trades" with $20 \%$; in the third group, the criteria "Spaces' use efficiency" has $11 \%$ of the weight ${ }^{3}$ (Table 1).

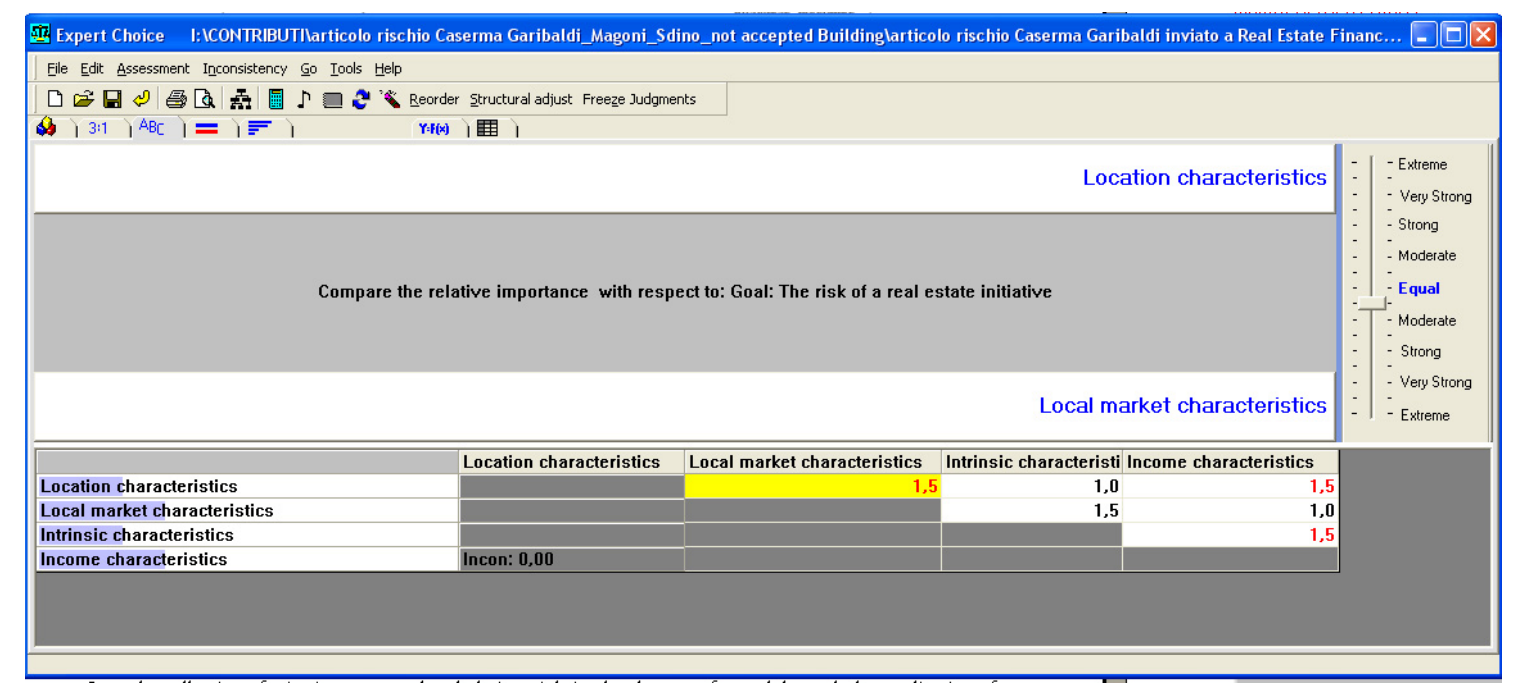

Figure 2. The pairwise comparison matrix of the macro-criteria's groups.

2 All the pairwise comparison are developed using the software Export Choice (expert choice ${ }^{\circledR}$-USA).

3 The weight of a single criteria respect to the overall result of the real estate initiative can be obtained by multiplying the relative weight of each criteria with the weight of the membership group (e.g., the overall weight of "Use" is $9 \%(30 \% \times 30 \%)$. 
Table 1. Tool's criteria and their weights.

\begin{tabular}{|c|c|c|c|c|}
\hline \multirow{2}{*}{\multicolumn{2}{|c|}{$\begin{array}{l}\text { CRITERIA } \\
\text { IOCATINCHARACTERISTICS }\end{array}$}} & \multicolumn{3}{|c|}{ WEIGHT } \\
\hline & \\
\hline \multicolumn{5}{|c|}{$\begin{array}{l}\text { Economic, social, and environmental influence of the context in which the object of the rating is placed; in the first section, "National } \\
\text { environment", this context is meant at a macro scale, national, then, in the "extrinsic characteristics" section, at the scale of the city, } \\
\text { neighborhood, and specific area. }\end{array}$} \\
\hline \multicolumn{5}{|l|}{ National Environment } \\
\hline 1. Natural events & $\begin{array}{ll}\text { - } & \text { Natural disasters } \\
\text { - } & \text { Man-made disasters } \\
\text { - } & \text { Pollutant emissions }\end{array}$ & $15 \%$ & \multirow{4}{*}{$25 \%$} & \multirow{14}{*}{$20 \%$} \\
\hline $\begin{array}{l}\text { 2. Demographic and social } \\
\text { development }\end{array}$ & $\begin{array}{ll}- & \text { Population growth } \\
\text { - } & \text { GDP per capita } \\
\text { - } & \text { Unemployment }\end{array}$ & $20 \%$ & & \\
\hline $\begin{array}{l}\text { 3. Overall economic development and } \\
\text { international attractiveness }\end{array}$ & $\begin{array}{ll}- & \text { GDP growth } \\
- & \text { Inflation } \\
- & \text { Exchange rate volatility } \\
- & \text { Economic structure } \\
- & \text { Infrastructures } \\
- & \text { International competitiveness }\end{array}$ & $40 \%$ & & \\
\hline $\begin{array}{l}\text { 4. Political, law, taxation, and } \\
\text { currency conditions }\end{array}$ & $\begin{array}{ll}- & \text { Corruption } \\
- & \text { Application of contracts } \\
& \text { and law } \\
- & \text { Restrictions on assets purchase } \\
\text { - } & \text { Taxes }\end{array}$ & $25 \%$ & & \\
\hline \multicolumn{4}{|l|}{ Extrinsic Characteristics } & \\
\hline 5. Size of the urban center & & $15 \%$ & & \\
\hline 6. Closeness to the city center & & $15 \%$ & & \\
\hline 7. Social environment & & $10 \%$ & & \\
\hline 8. Environmental context & & $8 \%$ & $75 \%$ & \\
\hline 9. Public transportations & & $10 \%$ & & \\
\hline 10. Free parking places & & $8 \%$ & & \\
\hline 11. Public services & & $13 \%$ & & \\
\hline 12. Commercial services & & $12 \%$ & & \\
\hline 13. Closeness to attracting poles (natur & al/artistic/recreational) & $10 \%$ & & \\
\hline \multicolumn{5}{|c|}{ 2. LOCAL MARKET CHARACTERISTICS } \\
\hline \multicolumn{5}{|c|}{$\begin{array}{l}\text { Overall market performance, with reference to the specific area of the object of rating. It is an assessment carried out at an intermediate } \\
\text { scale, in which the characteristics of the asset are not considered. }\end{array}$} \\
\hline 14. Use & & $30 \%$ & & \multirow{5}{*}{$30 \%$} \\
\hline 15. Municipal taxation & & $10 \%$ & & \\
\hline 16. Number of trades & & $20 \%$ & & \\
\hline 17. Sector's rental fees & & $15 \%$ & & \\
\hline 18. Demand/supply alignment & & $25 \%$ & & \\
\hline \multicolumn{5}{|l|}{ 3. INTRINSIC CHARACTERISTICS } \\
\hline \multicolumn{5}{|c|}{$\begin{array}{l}\text { Characteristics of the specific asset; some are hardly quantifiable and are attributable to design choices and property management } \\
\text { approaches. They relate to the building's appearance, its conservation status, its efficiency and usability. }\end{array}$} \\
\hline 19. Aesthetic attractiveness & & $10 \%$ & & \multirow{11}{*}{$20 \%$} \\
\hline 20. Attractiveness-Innovation & & $5 \%$ & & \\
\hline 21. Main facilities and services (heating & /electrical/water installations) & $10 \%$ & & \\
\hline 22. Ancillary facilities and services & & $7 \%$ & & \\
\hline 23. Installations maintenance & & $10 \%$ & & \\
\hline 24. Energy efficiency & & $8 \%$ & & \\
\hline 25. Accessibility & & $12 \%$ & & \\
\hline 26. Materials and constructive choices & & $10 \%$ & & \\
\hline 27. Spaces' use efficiency & & $11 \%$ & & \\
\hline 28. Fungibility & & $10 \%$ & & \\
\hline 29. Building maintenance & & $7 \%$ & & \\
\hline
\end{tabular}


Table 1. Cont.

\begin{tabular}{|c|c|c|c|}
\hline CRITERIA & & \multicolumn{2}{|c|}{ WEIGHT } \\
\hline \multicolumn{4}{|c|}{$\begin{array}{l}\text { Characteristics of the positive cash flows that are expected to guarantee the financial } \\
\text { sustainability of the operation. }\end{array}$} \\
\hline 30. Conditions of the lessor/occupier & $\begin{array}{ll}- & \text { Market's sector } \\
- & \text { Credit rating } \\
- & \text { Number of lessees }\end{array}$ & $30 \%$ & \multirow{4}{*}{$30 \%$} \\
\hline 31. Condition of vacancy/release/default & & $25 \%$ & \\
\hline 32. Non-recoverable operational costs & & $20 \%$ & \\
\hline 33. Current legislation & & $25 \%$ & \\
\hline
\end{tabular}

\section{Proposal of a Risk-Rating Tool}

Under such circumstances, the proposed tool is a standardized procedure, aimed at highlighting risks connected to real estate investments within their reference market.

To achieve organic ratings, initially made on individual criteria, a weighting system is used that enables providing final, comprehensive results, consistent with the reality of the specific situation. In this way, it follows a final rating that guarantees transparency of the process, comprehensibility of the results, and comparability with other valuations.

From a methodological perspective, the rating carried out is, thus, based on the valuation of the specific level of risk of each of the 33 criteria.

Those have been individually characterized, according to their peculiar nature and relevance.

\section{Risk Rating of the Caserma Garibaldi's Re-Functionalization}

This tool has been used for the rating of Caserma Garibaldi, a barracks in the process of disposal located in Piazza Sant'Ambrogio in Milan (Italy) and currently owned by the State Police. The rating falls within the scope of operations for the pre-feasibility verifications of its substitution with the Catholic University of Sacred Heart carried out in 2015 as a result of the re-functionalization of the Caserma Montello which was better suited to the State Police's needs.

Therefore, the risk rating has been carried out referring to the situation in 2015 and it integrates the report on the review of the Caserma Garibaldi's market value estimate report (originally drafted by the State Property Agency) by Polytechnic of Milan's ABC Department. In this context, the rating's aim is to verify what has emerged from the above-mentioned review: namely that, for the typological, geographical, and legislative characteristics of the asset, it cannot reasonably host any other functional destination than the academic one. In fact, in its valuation, the State Property Agency envisages a future use of the building dedicated to the services sector (offices, etc.; scenario 2), which departs from the one initially considered (university; scenario 1). This second option would have an actual positive impact on the market value, but it would also show obstacles for its capacity to be absorbed by the market and for the rather incomplete operation's state of progress.

Specifically, the Caserma Garibaldi is a real estate complex with a stereometric rectangular structure $(143 \mathrm{~m} \times 130 \mathrm{~m})$, which opens itself on the inside with an inner courtyard of about 9000 square meters; it is located near the campus of the Catholic University of Sacred Heart, located in Largo Agostino Gemelli.

Therefore, two compared ratings have been performed, respectively, for:

1. the risks connected to the university use (scenario 1); and

2. the risk connected to the services use (offices; scenario 2).

For each of the 33 criteria the risk level has been evaluated on a scale from 1 (null risk) to 10 (maximum risk) evaluating the state/condition within the configured scenario; the score takes into account the status of the characteristic in terms of the conditions configured in the project or (if any) 
detected in reality (Table 2). The sum of multiplications between the scores attributed to the individual criteria and their respective weights represents the level of risk for each group of criteria (Table 2).

The macro-criteria of Location receives a (relatively) low rating, of $4 / 10$, that is the same for both the scenarios since it assesses a systemic risk that is not directly linked with the peculiarities of the asset.

The macro-criteria of Local Market, on the other hand, shows some dissimilarities between the two scenarios: 2 for the first and 6 for the second. In fact, within this macro-criteria, the characteristics of the specific market's sector are now assessed; therefore, for how the situation was in 2015, the tertiary sector reveals a worse state of health.

The spatial and structural characteristics of this building, which is subject to historical and architectural constraints, such as particularly large corridors that lead to wide spaces, adapt well to academic needs.

This leads to a rating for the Intrinsic characteristics risk that is far lower for the academic scenario (5) than for the tertiary one (10) since the latter would require a lot more resources (time and money) for the optimization of spaces. Finally, also the ratings of the Income Characteristics macro-criteria are deeply affected by the specific contingencies of the two scenarios since, for the first hypothesis, an actual purchaser has already been found in the subject of Catholic University of Sacred Heart, while the other still has to face the difficulty of finding a reliable future buyer.

Table 2. Risk rating of the two options with explanation of those criteria whose ratings are different between the two scenarios.

\begin{tabular}{|c|c|c|c|}
\hline & & \multicolumn{2}{|c|}{ SCENARIO } \\
\hline & & $\begin{array}{c}1 \\
\text { UNIVERSITY }\end{array}$ & $\begin{array}{c}2 \\
\text { SERVICES }\end{array}$ \\
\hline \multicolumn{2}{|c|}{ 1. LOCATION CHARACTERISTICS } & 4 & 4 \\
\hline \multicolumn{2}{|c|}{ National environment } & 7 & 7 \\
\hline \multicolumn{2}{|c|}{ 1. Natural events } & 8 & 8 \\
\hline \multicolumn{2}{|c|}{ 2. Demographic and social development } & 7 & 7 \\
\hline \multicolumn{2}{|c|}{ 3. Overall economic development and international attractiveness } & 6 & 6 \\
\hline \multicolumn{2}{|c|}{ 4. Political, law, taxation and currency conditions } & 8 & 8 \\
\hline \multicolumn{2}{|c|}{ Extrinsic characteristics } & 3 & 3 \\
\hline \multicolumn{2}{|c|}{ 5. Size of the urban center } & 1 & 1 \\
\hline \multicolumn{2}{|c|}{ 6. Closeness to the city center } & 1 & 1 \\
\hline \multicolumn{2}{|c|}{ 7. Social environment } & 4 & 4 \\
\hline \multicolumn{2}{|c|}{ 8. Environmental context } & 4 & 4 \\
\hline \multicolumn{2}{|c|}{ 9. Public transportations } & 2 & 2 \\
\hline \multicolumn{2}{|c|}{ 10. Free parking places } & 7 & 7 \\
\hline \multicolumn{2}{|c|}{ 11. Public services } & 1 & 1 \\
\hline \multicolumn{2}{|c|}{ 12. Commercial services } & 3 & 3 \\
\hline \multicolumn{2}{|c|}{ 13. Attracting poles } & 1 & 1 \\
\hline \multicolumn{2}{|c|}{ 2. LOCAL MARKET CHARACTERISTICS } & 2 & 6 \\
\hline 14. Use & $\begin{array}{l}\text { University: there is almost no risk since the change of use to a } \\
\text { university is already envisaged by the Territorial Government } \\
\text { Plan and there is an interested buyer (Catholic University of } \\
\text { Sacred Heart). } \\
\text { Services: in Milan (in 2015), there is an overabundance of the } \\
\text { offer within this specific market sector. This leads to an } \\
\text { increase of the discount applied within the negotiation of } \\
\text { 13.5-15\%, to a stabilization of the average selling times in } \\
\text { around } 9.3 \text { months, and to the average rental times in around } \\
\text { seven months. These data reveal the poor health of the sector. } \\
\text { However, as concerns the annual average rate of return } \\
\text { guaranteed by the sub-sector this is proven a good source of } \\
\text { investments, being outperformed only by retail. }\end{array}$ & 1 & 5 \\
\hline
\end{tabular}


Table 2. Cont.

\begin{tabular}{lcc}
\hline & SCENARIO & \multicolumn{1}{c}{$\begin{array}{c}2 \\
\text { SERVICES }\end{array}$} \\
\hline 2. LOCAL MARKET CHARACTERISTICS & UNIVERSITY & $\mathbf{2}$ \\
\hline 15. Municipality taxation & 7 & 7 \\
\hline
\end{tabular}

University: there is almost no risk since the buyer has already been identified.

$\begin{array}{ll}\text { 16. Number of trades } & \text { Services: with a NTN (number of normalized transactions) of } 629 \\ \text { and an IMI (index of intensity of the real estate market) of } 1.51 \%\end{array}$ and an IMI (index of intensity of the real estate market) of $1.51 \%$
the health of Milan's tertiary sector is relatively better than the national sector's average, but it shows signs of the crisis that affects the whole market (del Territorio 2014).

\begin{tabular}{lll}
\hline 17. Sector's rental fees & 3 & 3 \\
\hline
\end{tabular}

University: the demand is guaranteed by the interest shown by the Catholic University of the Sacred Heart.

18. Demand/supply Services: in its proposal, the State Property Agency does not alignment asset and, consequently, the potential absorption of a property of such size and type. Moreover, the stillness of the tertiary segment emerges from the imbalance between supply and demand, with situations of unsold and vacancy of over $12 \%$ (Saaty 1990).

\begin{tabular}{lcc}
\hline 3. INTRINSIC CHARACTERISTICS & $\mathbf{5}$ & $\mathbf{1 0}$ \\
\hline 19. Aesthetic attractiveness & 1 & 8 \\
\hline 20. Attractiveness_-Innovation & 8 & 7 \\
\hline 21. Main facilities and services & 7 & 7 \\
\hline 22. Ancillary facilities and services & 7 & 7 \\
\hline 23. Installations maintenance & 7 & 7 \\
\hline 24. Energy efficiency & 2 & 2 \\
\hline 25. Accessibility & 4 \\
\hline 26. Materials and constructive choices & 4
\end{tabular}

The property is bound by the D.Lgs. n. 42/2004 (Legislative Decree); according to that, the spatial setting of the property cannot be

27. Spaces' use efficiency deeply transformed. This asset is thus poorly usable for every destination except the public ones, as it would result in a large waste of surface.

In recognition of the artistic and historical value of the good, no intervention that alters its typological system is permitted, in accordance with the D.lgs. n. 42/2004 (Legislative Decree). In this sense, in the case of a change in the users' needs, substantial adaptations are prevented.

28. Fungibility

The wide corridors are a limit to the flexibility of spaces since they cannot be adjusted even if they are poorly effective. In addition,

allowed interventions are difficult and long to complete because of the building's traditional style.

It is, therefore, desirable, for the accommodation of new functions,

a future use that is consistent with the original interior distribution.

\begin{tabular}{llc}
\hline 29. Building maintenance & 7 & 7 \\
\hline 4. INCOME CHARACTERISTICS & $\begin{array}{l}\text { University: there is almost no risk since the buyer has already } \\
\text { been identified. } \\
\text { Services: since the lessee has not yet been identified, this sector } \\
\text { cannot be evaluated; this implies the presence of a medium-high } \\
\text { risk due to the uncertainty of the object of the rating. }\end{array}$ & 1 \\
$\begin{array}{ll}\text { 30. Conditions of the } \\
\text { lessor/occupier }\end{array}$ & $\begin{array}{l}\text { University: there is almost no risk since the buyer has already } \\
\text { been identified. } \\
\text { Services: since the lessee has not yet been identified, his solvency } \\
\text { cannot be evaluated; this implies the presence of a medium-high } \\
\text { insolvency risk due to the uncertainty of the object of the rating. }\end{array}$ & 1 \\
\hline $\begin{array}{l}\text { 31. Condition of } \\
\text { vacancy/release/default }\end{array}$ & 8 \\
\hline 32. Non-recoverable operational costs & 6 & 6 \\
\hline Current legislation & $\begin{array}{l}6 \\
\text { TOTAL RISK-RATING: Rc }\end{array}$ & 6 \\
\hline
\end{tabular}


For each scenario, the overall risk rating $\left(\mathrm{R}_{C}\right)$ is then calculated by multiplying the score of each macro group of criteria (characteristics) for the respective weight ${ }^{4}$.

The scenario 1 (university) have an overall risk rating of 3 while scenario 2 (services) has an overall risk value of 6 . The transformation of the Caserma Garibaldi into public services (university), as it is already envisaged in the Territorial Government Plan, is not threatened by bureaucratic obstacles, thus, it is considered to have reached a complete state of progress.

The transformation of Caserma Garibaldi into offices, however, cannot be considered enforceable in short time: currently the former barracks, in accordance with the existing urban instrumentation, is still configurable only as a building for "public services and for public interest".

Even though the legislation contemplates changes of use for public properties, it is unrealistic to consider this variation as already completed, especially within a complex administrative reality such as the Italian one; therefore, the state of progress of the second option can be considered halfway through, at 50\%. Differently, the operation's stage of completion for university use is already established by the public administration (100\% state of progress) (Table 3$)$.

Table 3. Operation's stage of completion coefficient for each scenario.

\begin{tabular}{lcc}
\hline & \multicolumn{2}{c}{ SCENARIO } \\
\hline & 1 & 2 \\
Operation's stage of completion: coefficient "a" & UNIVERSITY & SERVICES \\
\hline
\end{tabular}

For each scenario, this different state of development represents an additional risk factor; the panel's components assign to his risk factor a score equal to 3.

The overall factor risk of each scenario can be evaluated through the following formula:

$$
\text { Final risk-rating }=\mathrm{Rf}=\mathrm{Rc}+3 \times(1-\mathrm{a})
$$

where "a" is the operation's stage of completion and 3 is the score assigned to the additional risk factor.

In conclusion, the application of the proposed tool to the case study results in two very different ratings: 3 for scenario 1 (university) and 7.5 for scenario 2 (services) ${ }^{5}$.

The risk rating for the use of the former Caserma Garibaldi as a further extension of the campus of the Catholic University of Sacred Heart remains relatively low while the one based on the hypothesis of the State Property Agency is dangerously high, partly because of its still undefined nature and its lack of considerations about the market's conditions.

\section{Conclusions}

As a response to the deep crisis of recent years, the decision whether to develop a real estate investment, or the choice between two or more alternative investments must go through a process of risk analysis. For this reason, tools that allow the acquisition of a global perspective of the risks incurred across the whole operation are required more than ever.

The objective of the case study is to experiment with a useful evaluation model to define the level of risk inherent a real estate investment; the proposed model-based on the professional and technical expertise of the component's panel (architects, engineers, etc.), intends to respond to this need by systemizing all the major risks through an integrated approach and giving directions for their analytical valuation.

4 For the scenario 1 (university use): Rc1 $=4 \times 0.20+2 \times 0.30+3 \times 0.20+3 \times 0.30=3$; for the scenario 2 (services use): Rc2 = $4 \times 0.20+6 \times 0.30+10 \times 0.20+6 \times 0.30=6$.

5 For the scenario 1 : Rc1 $=3+3 \times(1-1)=3$; for the scenario 2 : Rc2 $=6+3 \times(1-0.5)=7.5$. 
The panel have selected four macro-categories of characteristics (or criteria) and 33 characteristics (or sub-criteria) that influence the result of a real estate initiative and which state can represent a factor risk; most of them are aligned to the risk factors selected by other researchers for real estate investments (e.g., business, management, financial, environmental, and use risk factors (Cacciamani 2003; Haimes and Leach 1984)).

Results that emerged from its application to the case study are aligned with the decisions that, later on, the public administration has actually taken. In fact, the latter has opted for an investment that, even if it initially appeared less profitable than its alternative, after a deepened risk analysis, it has been proven to be safer and, therefore, the most convenient.

When there are two or more investment alternatives with the same amount of potential revenues, the rational investor is inclined to choose the less risky one and, vice versa, when there are different options with the same amount of risk, he will always choose the one that brings the higher profit.

Therefore, since investors tend to be risk-averse, it is necessary that they valuate not only the possible income, but rather the profitability adjusted according to the relative risk. In fact, for the success of an operation, it is not enough that the net present value is positive (Bravi and Fregonara 2008), it is also necessary that the internal rate of return is higher than a threshold that is defined on a case-by-case basis in accordance with the magnitude of the incurred risk.

The results obtained must be improved and tested in other case studies with different scenarios (other area and building uses like residential, etc.) in order to define if the characteristic and their weights are the same as those selected in this case study.

Author Contributions: L.S. conceived and designed the case-study and analyzed the data; P.R. performed the case-study and analyzed the data; S.M. collected the data; L.S. and P.R. wrote the paper.

Conflicts of Interest: The authors declare no conflict of interest.

\section{References}

Baroni, Michel, Fabrice Barthélémy, and Mahdi Mokrane. 2008. Un nouvel indice de risque immobilier pour le marché résidentiel parisien. Revue Économique 59: 99-118. [CrossRef]

Benedetto, Manganelli. 2015. Real Estate Investing: Market Analysis, Valuation Techniques and Risk Management. Cham: Springer International Publishing.

Bourassa, Steven C., Donald R. Haurin, Jessica L. Haurin, Martin Hoesli, and Jian Sun. 2009. House price changes and idiosyncratic risk: The impact of property characteristics. Real Estate Economics 37: 259-78. [CrossRef]

Bravi, Marina, and Elena Fregonara. 2008. Promozione e Sviluppo Immobiliare. Analisi dei Processi e Tecniche di Valutazione. Torino: Celid.

Cacciamani, Claudio. 2003. IL Rischio Immobiliare-Una Soluzione di Rating Dell'investimento Immobiliare. Milano: Egea.

Capozza, Dennis R., and Gregory M. Schwann. 1990. The value of risk in real estate markets. Journal of Real Estate Finance and Economics 3: 117-40. [CrossRef]

Cecconi, Fulvio Re, Lavinia C. Tagliabue, Sebastiano Maltese, and Martina Zuccaro. 2017. A Multi-criteria framework for decision process in retrofit optioneering through interactive data flow. Procedia Engineering 180: 859-69. [CrossRef]

D'alpaos, Chiara, and Rubina Canesi. 2014. Risk assessment in Real Estate investments in times of global crisis. WSEAS Transactions on Business and Economics 11: 369-78.

de FSM Russo, Rosaria, and Roberto Camanho. 2015. Criteria in AHP: A systematic review of literature. Procedia Computer Science 55: 1123-32. [CrossRef]

Degennaro, Emanuele. 2008. La Finanziarizzazione del Mercato Immobiliare. Bari: Cacucci.

del Territorio, Agenzia. 2014. Rapporto Immobiliare 2014-II Settore Residenziale; Roma: Osservatorio del Mercato Immobiliare e Servizi Estimativi, Agenzia delle Entrate.

Festa, Maurizio, Erika Ghiraldo, and Alessandra Storniolo. 2012. Analisi dei cicli del mercato immobiliare: Un'applicazione sui dati italiani. Territorio Italia 1: 89-109. 
Haimes, Yacov Y., and Mark R. Leach. 1984. Risk assessment and management in a multiobjective framwork. In Decision Making with Multiple Objectives. Edited by Yacov Y. Haimes and Vira Chankong. Berlin and Heidelberg: Springer.

Ho, William. 2008. Integrated analytic hierarchy process and its applications-A literature review. European Journal of Operational Research 186: 211-28. [CrossRef]

Ho, William, and Xin Ma. 2017. The state of the art integrations and applications of the analytic hierarchy process. European Journal of Operational Research, 1-16. [CrossRef]

Ho, Daniel, Graeme Newell, and Anthony Walker. 2005. The importance of Property-specific attributes in assessing CBD office building quality. Journal of Property Investment E Finance 23: 424-44.

International Valuation Standards Council. 2013. International Valuation Standards. London: International Valuation Standards Council.

Janssen, Jos, Bert Kruijt, and Barrie Needham. 1994. The honeycomb Cycle in Real Estate. The Journal of Real Estate Research 9: 237-52.

Jiang, Gen-mou, Zhen-peng Hu, and Jun-yan Jin. 2007. Quantitative evaluation of real estate's risk based on AHP and simulation, systems engineering. Theory \& Practice 27: 77-81.

Knight, Frank Hyneman. 1921. Risk, Uncertainty, and Profit. New York: Hart, Scaffner and Marx.

Kozioł-Kaczorek, Dorota. 2014. The use of combined multicriteria method forthe valuation of real estate. Optimum, Studia Ekonomiczne 5: 219-35.

Kušar, Matej, Maruška Šubic Kovač, and Jana Šelih. 2013. Selection of efficient retrofit scenarios for public buildings. Procedia Engineering 57: 651-56. [CrossRef]

Lin, Chin-Tsai, and Jun-Kun Lin. 2013. Fuzzy-GIS approach for applying the AHP multi-criteria decision-making model to evaluate real estate purchases. Journal of Testing and Evaluation 41: 978-89. [CrossRef]

Maggi, Maurizio. 2014. La Casa Non è Più il Bene Rifugio. Ora è Diventata un Incubo. January 16. Available online: http:/ / espresso.repubblica.it/affari/2014/01/13/news/la-casa-non-e-piu-il-bene-rifugio-ora-ediventata-un-incubo-1.148598 (accessed on 16 February 2017).

Manganelli, Benedetto, Pierluigi Morano, and Francesco Tajani. 2014. Risk assessment in estimating the capitalization rate. WSEAS Transactions on Business and Economics 11: 199-208.

Nassim, Nicholas Taleb. 2007. The Black Swan: The Impact of the Highly Improbable. London: Penguin.

Palicki, Sławomir. 2015. Multi-criteria assessment of public space from the social perspective. Real Estate Management and Valuation 23: 24-34. [CrossRef]

Peng, Liang, and Thomas G. Thibodeau. 2017. Idiosyncratic risk of house prices: Evidence from 26 million home sales. Real Estate Economics 45: 340-75. [CrossRef]

Reddy's Group. 2016. IL Mercato Immobiliare resIdenziale Italiano. March. Available online: http: / / www.golfpeople.eu/wp-content/uploads/2016/05/Il-mercato-imm.-italiano-mar-2016.pdf (accessed on 25 May 2017).

Ribeiro, Mónica I. F., Fernando A. F. Ferreira, Marjan S. Jalali, and Ieva Meidutè-Kavaliauskienè. 2017. A fuzzy knowledge-based framework for risk assessment of residential real estate investments. Technological and Economic Development of Economy 23: 140-56. [CrossRef]

Saaty, Thomas L. 1980. The Analytic Hierarchy Process. New York: McGraw-Hill.

Saaty, Thomas L. 1988. Multicriteria Decision Making-The Analytic Hierarchy Process. Planning, Priority Setting, Resource Allocation. Pittsburgh: RWS Publishing.

Saaty, Thomas L. 1990. Decision Making for Leaders-The Analytic Hierarchy Process for Decisions in a Complex World. Pittsburgh: RWS Publishing.

Shao, Adam W., Katja Hanewald, and Michael Sherris. 2015. Reverse mortgage pricing and risk analysis allowing for idiosyncratic house price risk and longevity risk. Insurance: Mathemathics and Economics 63: 76-90. [CrossRef]

Tecnoborsa. 2011. Codice Delle Valutazioni Immobiliari-Italian Property Valuation Standard, 4th ed. Roma: Tecnoborsa, S.c.p.a.

TEGoVA. 2003. European Property and Market Rating. Bruxelles: TEGoVA.

TEGoVA. 2012. European Valuation Standards. Bruxelles: TEGoVA. 
Wang, Cheng. 2013. Family house-purchase decision model based on analytic hierarchy process. Applied Mechanics and Materials 423-26: 2973-76. [CrossRef]

Zheng, Xian, K. W. Chau, and C. M. Eddie. 2015. Liquidity risk and cross-sectional return in the housing market. Habitat International 49: 426-34. [CrossRef]

(). (1) (C) 2018 by the authors. Licensee MDPI, Basel, Switzerland. This article is an open access article distributed under the terms and conditions of the Creative Commons Attribution (CC BY) license (http:/ / creativecommons.org/licenses/by/4.0/). 